\title{
STABILITY AND GROWTH PACT
}

Marina Kesner-Škreb, MSc

Institute of Public Finance, Zagreb
Glossary*

UDC 327.56(4-12)

JEL E62
The Stability and Growth Pact is an agreement relating to fiscal policy among the member states of the EU. It refers to the third phase of the Economic and Monetary Union (EMU), that is to irrevocably fixed exchange rates and the introduction of the single currency, the euro. Implementation started on January 1, 1999, in order to make sure that the EMU member states maintained fiscal discipline after the introduction of the euro, the single currency. The member states that introduced the euro have to maintain the Maastricht convergence criteria, and the Stability and Growth Pact makes sure that these are enforced. States have to respect the following fiscal criteria:

- General government budget deficit: the general government budget deficit expressed as a percentage of gross domestic product (GDP) must not exceed 3\% as of the end of the preceding financial year. If this it is not possible, then the deficit can be temporarily above the $3 \%$ level, but must still be close to it.
- The public debt: the gross general government debt must not exceed $60 \%$ of GDP as of the end of the preceding financial year. If this is not so, the proportion of the debt must show a tendency to considerable reduction and must converge on the reference value with a satisfactory dynamics.

In a formal sense, the Pact was adopted by a resolution of the European Council (in Amsterdam, June 17, 1997) and with two regulations of the Council of July 7 , 1997, which elaborated in detail the technical specificities of the pact from the point of view of supervising the budgetary items and the coordination of economic policies if an excessive deficit should arise.

In the EU, economic policy is characterised by a centralised monetary policy that is in the remit of the European Central Bank - ECB, and a decentralised fiscal policy, which remains within the jurisdiction of the national governments of the member states. Healthy government finances contribute to the achievement and maintenance of price stability and hence of sustainable

\footnotetext{
* Received: February 25, 2008.
}

Accepted: March 4, 2008. 
economic growth. Hence common rules for the running of fiscal policies at national levels are defined and established at EU level. These rules were incorporated into the provisions of the Treaty on European Unity at Maastricht in 1992, and, particularly, in the Stability and Growth Pact, and relate to fiscal criteria - the size of the budgetary deficit and of the public debt - that member countries must satisfy in order to be able to introduce the euro as the national currency, or to achieve and maintain stable positions within the EMU.

The Stability and Growth Pact was initially proposed by German finance minister Theo Waigel in the mid-1990s. For many years Germany had maintained high rates of growth concurrently with a low inflation and expected that it would be able to ensure the continuation of such a policy by the implementation of the Stability and Growth Pact, which would limit the contribution of the member states to inflationary pressures in the European economy.

In the mid-term the member states undertook measures to balance their budgets and by March 1, 1999, had presented stabilisation programmes to the Council and the Commission; these programmes were supplemented each following year. Countries that were not members of the EMU third phase, i.e., those that had not introduced the euro, had to submit convergence programmes.

The Stability and Growth Pact enables the Council to penalise every member state that does not undertake appropriate measures in order to reduce excessive deficits (the excessive deficit procedure as it is called). Penalty measures have at the beginning the form of a non-interest-bearing deposit that can be turned into a fine if the deficit is not corrected in a period of two years. But there are no fixed rules to govern these penalty measures. They are on the whole a matter of the Council's subjective assessment about the circumstances in the origin of an excessive deficit.

The Pact has been criticised much for not being flexible enough and for being applied only to a single year and not over the whole of the economic cycle. There is some fear that constraints on public spending during economic crises could have a bad effect on the growth in member states.

Apart from this, the Pact has been enforced very inconsistently. In 2003 the Council of Ministers did not invoke the penalty provisions with respect to France and Germany when they were in difficulties. This was the culmination of several years of major issues in the introduction of the Pact and showed that one of the major problems in it was its weak enforceability. The Pact has been shown impossible to apply to the big countries, such as France and Germany, which were actually the main generators of the agreement, but which tend, because of their size and political influence, to be spared if they do offend against the Pact's provisions. For according to the Pact's definitions, these were countries that did have excessive deficits, and yet were not penalised.

Accepting these criticisms, in 2005 the Council softened the rules of the Stability and Growth Pact. The fundamental feature of the Pact is that the quantitative constraints of the original Pact - the budgetary deficit of $3 \%$ of GDP and the public debt of at most $60 \%$ of GDP - remained unchanged. However, the definition and implementation of the rules of the Pact have become somewhat different, more flexible. The first departure is that budgetary objectives will be reviewed every fourth year. A second new departure is that countries with a low public debt and a high growth potential will 
be allowed a budgetary deficit of $1 \%$ of GDP in the medium term. Highly indebted countries with a low potential growth have to aim for a balanced budget or even a surplus. Countries with a public debt greater than $100 \%$ of GDP will be asked to aim at a budgetary surplus. Also among the main elements of reform is the requirement for the strengthening of fiscal positions during good years, such good years being understood as those in which GDP is above the potential level. It is anticipated that in these years countries will reduce their potential deficit by 0.5 GDP percentage points.

\section{LITERATURE}

Brnčić, A. [et al.], 2005. Mali leksikon Europskih integracija [online]. Zagreb:
Ministarstvo vanjskih poslova i europskih integracija. Available from: [http://www. mvpei.hr/ei/download/2005/06/15/Mali leksikon.pdf].

EnterEurope - Vodič kroz informacije o Europskoj uniji [online]. Available from: [http://www.entereurope.hr].

Glossary [online]. Available from: [http://europa.eu/scadplus/glossary/index en.htm].

Šabić, A., 2006. [online] "Reform of the stability and growth pact" Financial Theory and Practice, 30 (3), 283-293. Available from: [http://www.ijf.hr/eng/ FTP/2006/3/sabic.pdf]. 